\title{
Chapter 1 \\ Expectations for Carbon Pricing in Japan in the Global Climate Policy Context
}

\author{
Satoshi Kojima and Kenji Asakawa
}

\begin{abstract}
Realizing a decarbonized society in consistent with the Paris Agreement, a fundamental transformation of the entire economic and social system is needed, and not only carbon intensive sectors but also all sectors and all stakeholders including households must be decarbonized. This chapter demonstrates increasing expectations for carbon pricing in Japan in this global policy context. After the review of the global trend of carbon pricing, historical progress of carbon pricing in Japan and the existing nation-wide carbon tax, i.e. the Global Warming Countermeasure Tax, is explained. There are also two sub-national carbon pricing schemes in Japan, Tokyo ETS and Saitama ETS, which are explained in Chaps. 6 and 7 respectively, and not focused in this chapter. We examine the claim that Japan has already implemented high level carbon pricing in terms of various forms of energy taxes. Based on the effective carbon rate which is defined by OECD as the sum of explicit carbon prices and fossil fuel taxes per carbon emission, the nationwide average effective carbon rate of Japan is lower than the average effective carbon rates of OECD countries and its key partner countries. The current carbon pricing schemes in Japan are too modest to realize decarbonization transition and there is a room to upgrade them to exploit full potential of carbon pricing. This chapter discusses adequate levels of carbon prices in compatible with decarbonization transition.
\end{abstract}

Keywords Paris agreement - Decarbonization - Transition - Carbon pricing • Effective carbon rates

\section{Introduction}

The Paris Agreement adopted in December 2015 sets out the trend toward decarbonization, which calls for net zero GHG emissions by the latter half of this century. Along with this trend not a few countries have set ambitious emission reduction targets to address it, and among them Japan officially set an $80 \%$ reduction target for

\footnotetext{
S. Kojima $(\varangle) \cdot$ K. Asakawa

Institute for Global Environmental Strategies (IGES), Hayama, Japan

e-mail: kojima@iges.or.jp 
greenhouse gas (GHG) emissions by 2050 in the Plan for Global Warming Countermeasures adopted by the Cabinet in May 2016. The IPCC $1.5^{\circ} \mathrm{C}$ Special Report (IPCC 2018) published in November 2018 further corroborates this trend, and now international society seriously discusses decarbonization measures to reduce $\mathrm{CO}_{2}$ emissions to net zero around 2050. In order to realize such a decarbonized society, a fundamental transformation of the entire economic and social system is needed and not only carbon intensive sectors such as the power generation sector and the iron and steel sector but also all sectors and all stakeholders including households must be decarbonized.

How to realize such a fundamental transformation is apparently an extremely difficult question, but there are number of existing studies tackling this daunting task to answer this question and there seems to be a general agreement that carbon pricing is necessary to realize a fundamental systemic change toward a decarbonized society.

The Deep Decarbonization Pathways Project (DDPP), an international research project that aimed to chart a pathway to reach the 2050 reduction target using backcasting methods to be consistent with the Paris Agreement, placed carbon pricing as a key element in all policy packages (DDPP 2015). It is explained that the realization of decarbonization assumes that a large number of discrete (decentralized) actors will make the right choices, and carbon pricing is essential to harmonize such discrete decisions (DDPP 2015). Rockström et al. (2017), in their "Roadmap for Rapid Decarbonization" to achieve net zero $\mathrm{CO}_{2}$ emissions by 2050, stated that carbon pricing of at least USD 50/t- $\mathrm{CO}_{2}$ in 2020 for all $\mathrm{CO}_{2}$ emissions needs to be introduced, and that it needs to be raised to a level above USD 400/t- $-\mathrm{CO}_{2}$ by 2050 .

There are strong calls for carbon pricing from several influential stakeholders at the global level. At COP21 in December 2015, the Carbon Pricing Leadership Coalition (CPLC) was officially launched. As of 2019 CPLC brings together more than 33 national and sub-national governments, 162 private sector organizations, and 80 strategic partners representing NGOs, business organizations, and universities, aiming at promoting carbon pricing towards the long-term objective of introducing carbon pricing all over the world (World Bank 2019a). Actually it was not by chance that the launch of CPLC and the adoption of the Paris Agreement happened simultaneously at COP21. There was a strong synergy between these two events. The call for ambitious climate actions, through carbon pricing, by both heads of governments and CEOs of leading companies gave momentum to raise the level of ambition of the Paris Agreement, and ambitious climate goals stipulated in the Paris Agreement built momentum to introduce carbon pricing as a key instrument to attain the climate goals. From the business sector, the World Business Council for Sustainable Development (WBCSD) stated in their 2019 report that "carbon pricing mechanisms are critical to support the urgent efforts required to drive the transition towards a low carbon future and achieving the $1.5{ }^{\circ} \mathrm{C}$ goal" (WBCSD 2019, p. 6). As WBCSD (2019) declared, the time for debating the need for carbon pricing was over and it is time to strongly call for the need of carbon pricing as long-term polices towards decarbonized society.

Carbon pricing is expected to contribute to decarbonization through several functions. Two key functions are price signalling and revenue generation functions. The 
price signalling function means that carbon pricing improves economic efficiency by reflecting the cost of carbon emissions, i.e. the damage costs of climate change. Ideally carbon prices should be set at the true cost of carbon emissions, but in reality any level of carbon pricing will raise the relative prices of carbon intensive commodities and can contribute to mitigation. This function is common across all forms of explicit carbon pricing, including both carbon tax and cap-and-trade (emission trading system), and it makes low-carbon products relatively cheaper than carbonintensive alternatives, which results in steering consumers to make low-carbon choices, as well as making low-carbon business profitable and creating business opportunities. The revenue generation function means that revenues from the carbon pricing schemes can be utilised to finance climate actions. This function is limited to carbon taxes or cap-and-trade mechanisms with auction of emission allowances. This function may enable low-carbon and decarbonization investment, including infrastructure development, without which systemic changes towards decarbonized society cannot be materialised. In addition, a carbon tax with a clearly announced future price schedule may serve to inform the general public the strong commitment of governments to achieve climate goals and enable them to accommodate expected levels of carbon prices in their decision making, which is termed as an announcement effect. Through these functions, carbon pricing is expected to provide enabling conditions of a systemic transformation towards decarbonized society.

On the other hand, existing research on carbon pricing has advanced around either theoretical studies supporting that carbon pricing is the most cost-effective emission reduction measure (e.g., Pearce 1991; Schneider and Goulder 1997; Morotomi 2000; Nordhaus 2010) or research on the double dividend hypothesis (e.g., Fullerton and Metcalf 1997; De Mooij 2000; Arimura et al. 2018), which argues that emissions reductions and positive economic impacts can be achieved simultaneously by appropriating revenues from carbon pricing to reduce market-distorting taxes such as income tax and corporate tax. Tvinnereim and Mehling (2018) review empirical studies on carbon pricing, including examples of ex-post evaluations by econometric analysis, and point out that although the emission reduction effect of carbon pricing was empirically supported, the reduction effects were only in the range of a few percent to $10 \%$ even in countries that have introduced expensive carbon pricing, including Sweden, and does not support that carbon pricing is effective for the large emission reductions needed for decarbonization. Patt and Lilliestam (2018) claim that most of the existing theoretical studies on carbon pricing are based on the short-term and static demand-supply curves of neoclassical economics, but in order to handle system transitions such as decarbonization, a theoretical framework of transition theory from a long-term and dynamic perspective is needed, such as a decrease in supply price due to an increase in supply due to learning effects and a product value that is determined by regimes such as infrastructure, social networks and institutions.

This chapter demonstrates increasing expectations for carbon pricing in Japan in the context of global climate policy corresponding to the Paris Agreement, in particular the $1.5^{\circ} \mathrm{C}$ goal, with keeping mind of the abovementioned research gap. The following Sect. 2 explains the global trend of carbon pricing with introducing 
advanced cases of carbon pricing across the world. Section 3 explains historical progress of carbon pricing discussion in Japan and outlines the current nation-wide carbon pricing scheme, i.e. Global Warming Countermeasure Tax. There are also sub-national carbon pricing schemes in Japan, that is, ETSs in Tokyo and Saitama, of which explanation are provided in Chaps. 6 and 7 respectively, and this chapter focuses on carbon tax including the currently implemented Global Warming Countermeasure Tax. Section 4 argues that the current carbon pricing schemes in Japan are too modest and there is a room to upgrade them to exploit full potential of carbon pricing, with arguing expected price ranges in compatible with decarbonization transition, and Sect. 5 concludes this chapter.

\section{Global Trend of Carbon Pricing}

\subsection{Carbon Pricing Initiatives in the World}

Since the first carbon tax was introduced by Finland in 1990, only a limited number of European countries implemented carbon tax and the emissions covered by these schemes were very small until the early 2000s. In 2005 EU-ETS was started and the emissions covered by carbon pricing significantly increased, around $4 \%$ of global emissions (World Bank 2019b). In 2007 the number of carbon pricing initiatives reached 10, and 4 years later the number of initiatives exceeded 20. Since then the number of initiatives have steadily increased, and as of April 2019, 46 countries and 28 cities/states/regions, which represent $56 \%$ of global greenhouse gas (GHG) emissions, have introduced carbon pricing initiatives, according to World Bank (2019b). The levels of carbon prices vary significantly across countries/schemes as shown in Fig. 1.

Currently three Nordic countries (Sweden, Norway and Finland), Switzerland, Liechtenstein and France set high carbon prices above USD 50/t- $\mathrm{CO}_{2}$, with Sweden implementing the highest carbon price of USD 127/t- $\mathrm{CO}_{2} .18$ initiatives employ moderate carbon prices between USD $10 / \mathrm{t}-\mathrm{CO}_{2}$ and USD $50 / \mathrm{t}-\mathrm{CO}_{2}$, and the remaining initiatives employ low carbon prices less than USD 10/t- $\mathrm{CO}_{2}$. Japan's

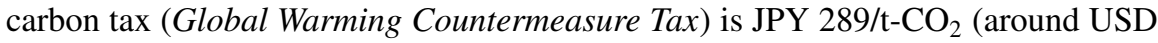
2.6/t- $\mathrm{CO}_{2}$ ), which is among the lowest carbon prices.

\subsection{Lessons Learned from Advanced Carbon Pricing Initiatives}

In order to make the debate over carbon pricing in Japan more productive and proactive towards decarbonization transition, advanced cases of carbon pricing in 


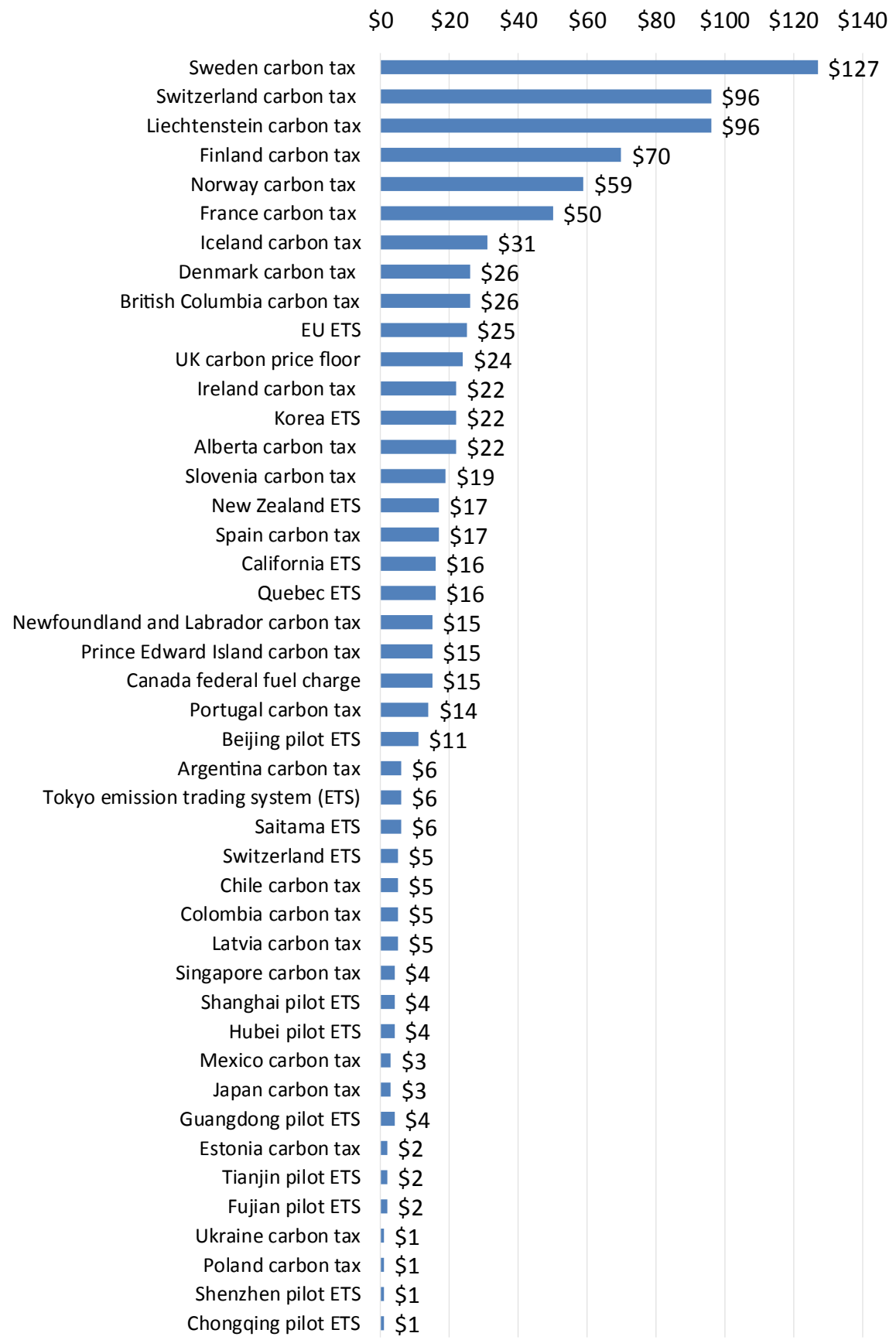

Fig. 1 Prices in existing carbon pricing initiatives. Source World Bank (2019b), adopted by the authors 
Europe, which were often introduced after intense debate with opponents, provide good reference cases.

In Germany, compared to Japan, ecological tax reform itself has become a political point of contention and has been elevated to a national debate through the election campaign. The lesson to be learned from this is that the larger the national debate became, the more each stakeholder's "real opinions" (the real points of contention) came up for discussion, rather than superficially contesting theoretical and academic points of contention (Kreiser et al. 2015). As a result, it was decided to focus on individual benefits, such as the international competitiveness, performance, and employment issues of the stakeholders affected by the carbon tax, particularly the manufacturing industry, rather than the macro and general discussion such as impacts on GDP growth rates. In this way, we believe that the political contentiousness has stimulated a wide range of stakeholders to discuss their "true feelings" and, because the issues were thoroughly addressed, it was possible to design the system for a carbon tax and other measures accordingly, and relatively quickly consensus was formed.

France was more concerned about the international competitiveness of its own industry, and discussion of border tax adjustment in cooperation with other countries was rendered in parallel with the introduction of a carbon tax and other measures (Asakawa et al. 2016). In EU, many countries have already traded emissions credits through EU-ETS and many countries have also introduced carbon taxes. Therefore, at least a fairer competitive market in terms of carbon pricing has been developed than in the other regions. Nevertheless, the fact that border tax adjustments were being considered suggests that international competitiveness is an issue that should be handled with caution.

In the United Kingdom, from the beginning of policy process the priority is given to stakeholder consultation in order to reflect the opinions of citizens and industry in the design of the system, including consideration for the energy poor (Force 1998). In response to industry concerns, the government exempted energy-intensive industries from taxation, but instead forced them to sign a climate change agreement with the government with voluntary reduction targets. This active adoption of a policy mix of agreements and carbon taxes is also instructive in designing carbon pricing in Japan.

In Sweden, the success factor of early introduction of carbon tax was the fact that tax on fossil fuels was sought as an alternative revenue source to income taxes that had been a high tax burden (Asakawa et al. 2016). This suggests that in addition to the importance of revenue neutrality, the choice of alternative taxes also contributes to public support. In addition, the abundance of biomass, which became an alternative heat source for local heat supply with the introduction of the carbon tax, could be another important factor in increasing public support.

\subsection{The Current Status of Effective Carbon Rates}

There is an argument that energy taxes also function as carbon pricing instruments. For example, taxation on fossil fuels provides incentives to reduce fossil 
fuels consumption and consequently has the same effect as a carbon tax, if we just focus on one type of fossil fuel. The important difference between carbon tax and energy tax is that the former tax rates per carbon content are identical across different types of fossil fuels while those of the latter differ between different fossil fuels, and in the worst case the latter could give incentive to increase carbon emissions through lowering relative price of high carbon content fossil fuel such as coal comparing with that of low carbon content fossil fuel such as natural gas. Bearing this caveat in mind, energy tax can be regarded as an extension of carbon pricing. Following this line of argument, OECD defines effective carbon rates (ECR) as the sum of explicit carbon prices (carbon taxes and ETS) and fossil fuel taxes per carbon emission, and estimates the effective carbon rates of OECD countries and its key partner countries as shown in Table 1 (OECD 2016).

Switzerland records the highest national average effective carbon rate at EUR 104.4/t- $\mathrm{CO}_{2}$, followed by Luxemburg (EUR 95.3/t-CO ${ }_{2}$ ) and Norway (EUR 93.0/t$\mathrm{CO}_{2}$ ). Interestingly the national average effective carbon rate of Sweden (EUR 69.3/t$\mathrm{CO}_{2}$ ) is significantly lower than its carbon tax rate (USD $127 / \mathrm{t}-\mathrm{CO}_{2}$ ), which means that substantial portion of carbon emissions are exempted from carbon tax.

The effective carbon rates vary greatly across sectors. In many countries including Japan, road transport energy is heavily taxed and is associated with much higher effective carbon rates than those of remaining energy usages, as shown in Table 1. For example, in Japan, the average effective carbon rate of road transport energy is high at EUR 188.3/t- $\mathrm{CO}_{2}$ while that of other energies is much low at EUR 7.7/t- $\mathrm{CO}_{2}$, which result in the country's average effective carbon rate at EUR 34.8/t- $\mathrm{CO}_{2}$.

\section{The Current Status of Carbon Pricing in Japan}

\subsection{The Current Carbon Pricing Initiatives in Japan}

Currently there are three carbon pricing initiatives in Japan, Tokyo ETS started in 2010, Saitama ETS started in 2011 and linked to Tokyo ETS, and the Global Warming Countermeasure Tax, a national carbon tax, started in 2012. As two local ETSs are addressed in the following Chap. 6 (Tokyo ETS) and Chap. 7 (Saitama ETS), this section focuses on the Global Warming Countermeasure Tax.

Japan introduced the Global Warming Countermeasure Tax in April 2012 after long discussion at the Central Environment Council. In particular, the Special Committee on Global Warming Countermeasures and Taxation, which was established under the Joint Committee of Comprehensive Policy and Global Environment, the Central Environment Council, from 2001 to 2003, carried out intensive discussions on carbon taxes with the aim of creating a basis for public debate on carbon taxes as a part of evaluation and review of the Charter of Countermeasures against Global Warming in 2004. Based on these discussions the Ministry of the Environment (MOE) submitted a series of tax proposals based on the examination of the 
Table 1 Effective Carbon Rates (ECR) of OECD Countries and Key Partner Countries

\begin{tabular}{|c|c|c|c|c|c|}
\hline & \multirow{2}{*}{$\begin{array}{l}\text { Overall } \\
\text { average ECR } \\
\left(\mathrm{EUR} / \mathrm{t}-\mathrm{CO}_{2}\right)\end{array}$} & \multicolumn{2}{|c|}{$\begin{array}{l}\text { All energy excluding road } \\
\text { transport energy }\end{array}$} & \multicolumn{2}{|c|}{ Road transport energy } \\
\hline & & $\begin{array}{l}\text { Share of } \\
\text { emissions } \\
(\%)\end{array}$ & $\begin{array}{l}\text { Average ECR } \\
\left(\text { EUR/t-CO }{ }_{2}\right)\end{array}$ & $\begin{array}{l}\text { Share of } \\
\text { emissions } \\
(\%)\end{array}$ & $\begin{array}{l}\text { Average ECR } \\
\left(\mathrm{EUR} / \mathrm{t}-\mathrm{CO}_{2}\right)\end{array}$ \\
\hline Australia & 21.2 & 82 & 2.4 & 18 & 106.6 \\
\hline Austria & 56.2 & 75 & 20.2 & 25 & 164.4 \\
\hline Belgium & 40.6 & 79 & 7.4 & 21 & 165.7 \\
\hline Canada & 10.7 & 73 & 3.4 & 27 & 30.6 \\
\hline Chile & 12.5 & 84 & 0.0 & 16 & 78.2 \\
\hline Czech & 33.2 & 84 & 6.7 & 16 & 172.3 \\
\hline Denmark & 80.3 & 77 & 47.4 & 23 & 190.4 \\
\hline Estonia & 29.1 & 87 & 9.5 & 13 & 160.4 \\
\hline Finland & 48.7 & 87 & 23.7 & 13 & 216.1 \\
\hline France & 65.8 & 67 & 9.7 & 33 & 179.9 \\
\hline Germany & 58.7 & 82 & 23.4 & 18 & 219.5 \\
\hline Greece & 60.4 & 82 & 20.7 & 18 & 241.4 \\
\hline Hungary & 35.4 & 77 & 5.0 & 23 & 137.4 \\
\hline Iceland & 80.1 & 58 & 18.1 & 42 & 165.6 \\
\hline Ireland & 71.9 & 73 & 20.6 & 27 & 210.6 \\
\hline Israel & 79.6 & 75 & 26.3 & 25 & 239.4 \\
\hline Italy & 60.4 & 82 & 20.4 & 18 & 242.7 \\
\hline Japan & 34.8 & 85 & 7.7 & 15 & 188.3 \\
\hline Rep. Korea & 28.4 & 87 & 9.8 & 13 & 153.3 \\
\hline Luxemburg & 95.3 & 31 & 5.8 & 69 & 135.5 \\
\hline Mexico & 2.7 & 69 & 0.2 & 31 & 8.1 \\
\hline Netherlands & 88.7 & 80 & 54.6 & 20 & 224.8 \\
\hline New Zealand & 30.5 & 67 & 1.2 & 33 & 90.2 \\
\hline Norway & 93.0 & 76 & 46.7 & 24 & 239.3 \\
\hline Poland & 28.6 & 85 & 10.6 & 15 & 130.6 \\
\hline Portugal & 48.4 & 72 & 6.6 & 28 & 156.1 \\
\hline Slovakia & 40.0 & 83 & 16.3 & 17 & 155.7 \\
\hline Slovenia & 67.8 & 62 & 16.6 & 38 & 151.5 \\
\hline Spain & 43.4 & 74 & 11.1 & 26 & 135.1 \\
\hline Sweden & 69.3 & 78 & 30.7 & 22 & 206.5 \\
\hline Switzerland & 104.4 & 64 & 21.5 & 36 & 251.7 \\
\hline Turkey & 39.2 & 85 & 7.6 & 15 & 218.6 \\
\hline UK & 75.5 & 77 & 14.3 & 23 & 280.6 \\
\hline
\end{tabular}


Table 1 (continued)

\begin{tabular}{l|l|l|l|l|c}
\hline & \multirow{2}{*}{$\begin{array}{l}\text { Overall } \\
\text { average ECR } \\
(\text { EUR/t-CO })\end{array}$} & \multicolumn{2}{l}{$\begin{array}{l}\text { All energy excluding road } \\
\text { transport energy }\end{array}$} & \multicolumn{2}{l}{ Road transport energy } \\
\cline { 3 - 6 } & & $\begin{array}{l}\text { Share of } \\
\text { emissions } \\
(\%)\end{array}$ & $\begin{array}{l}\text { Average ECR } \\
(\text { EUR/t-CO } 2)\end{array}$ & $\begin{array}{l}\text { Share of } \\
\text { emissions } \\
(\%)\end{array}$ & $\begin{array}{l}\text { Average ECR } \\
(\text { EUR/t-CO } 2)\end{array}$ \\
\hline USA & 5.7 & 72 & 0.8 & 28 & 18.4 \\
\hline Argentina & 33.0 & 77 & 3.7 & 23 & 130.9 \\
\hline Brazil & 3.8 & 72 & 1.8 & 28 & 9.1 \\
\hline China & 4.0 & 94 & 1.6 & 6 & 42.0 \\
\hline India & 2.9 & 93 & 1.0 & 7 & 29.1 \\
\hline Indonesia & 2.4 & 83 & 0.0 & 17 & 13.9 \\
\hline Russia & 0.0 & 92 & 0.0 & 8 & 0.1 \\
\hline South Africa & 13.7 & 91 & 3.0 & 9 & 122.1 \\
\hline
\end{tabular}

Source OECD (2016), adopted by the authors

characteristics of carbon taxes, institutional issues as taxes, the use of tax revenues, and preliminary estimation of the effects of carbon taxes. Table 2 shows changes in proposals made by MOE and the Central Environment Council until the introduction of the Global Warming Countermeasure Tax.

It is observed that basic features of the implemented Global Warming Countermeasure Tax as well as most proposals, except for those in 2003, 2004 and 2009, are low tax rate with spending tax revenue for global warming countermeasures. Kawakatsu et al. (2017) reported that the study group on possible tax system reform established by the Environmental Agency (the current MOE) already suggested in 1998 that a possible Japanese carbon tax should have a low tax rate and that the revenues should be solely used for GHG reduction, according to Environmental Agency (1997). In many countries carbon intensive sectors such as the fossil fuel industry, the iron and steel industry and the paper industry strongly oppose carbon pricing that significantly increases production costs if other conditions remain the same, and Japanese business community strongly opposed introducing the carbon tax, which was one of the factors explaining why the realized tax rate (JPY 289/t$\mathrm{CO}_{2}$ ) was much lower than the originally proposed rates (JPY 655/t- $\mathrm{CO}_{2}$ in the proposals during 2004-2008, and JPY 1,064/t- $\mathrm{CO}_{2}$ in the 2009 proposal).

Another interesting feature of carbon tax debate in Japan and the implemented Global Warming Countermeasure Tax is lack of double dividend perspective, which has been intensively discussed associated with carbon pricing and has provided orientation of green tax reform in many countries. The double dividend hypothesis claims that the reduction of externality by a carbon tax (the first dividend) and the effect of reducing market distortions caused by taxation (the second dividend) can be achieved simultaneously by using carbon tax revenues to reduce other taxes (Goulder 1995; Schob 2003). The original double-dividend hypothesis is that the tax revenue from the optimal solution for the first dividend, which is the Pigouvian tax, 
Table 2 Contents of tax proposals towards the Global Warming Countermeasure Tax

\begin{tabular}{|c|c|c|c|c|c|}
\hline $\begin{array}{l}\text { Proposal } \\
\text { date }\end{array}$ & Description & $\begin{array}{l}\text { Tax rate }(\mathrm{JPY} \\
\left.\text { per } \mathrm{t}-\mathrm{CO}_{2}\right)\end{array}$ & $\begin{array}{l}\text { Expected } \\
\text { mitigation } \\
\text { effects }\end{array}$ & $\begin{array}{l}\text { Tax revenue } \\
\text { (JPY billion } \\
\text { per year) }\end{array}$ & $\begin{array}{l}\text { Use of tax } \\
\text { revenue }\end{array}$ \\
\hline \multirow[t]{2}{*}{$\begin{array}{l}\text { August } \\
2003\end{array}$} & \multirow{2}{*}{$\begin{array}{l}\text { Preliminary } \\
\text { estimation by } \\
\text { the special } \\
\text { committee on } \\
\text { taxation for } \\
\text { global warming } \\
\text { countermeasure }\end{array}$} & $\begin{array}{l}927 \text { for all } \\
\text { fossil fuels }\end{array}$ & \multirow{2}{*}{$\begin{array}{l}\text { Kyoto } \\
\text { protocol } \\
\text { target of } 6 \% \\
\text { reduction } \\
\text { from } 1990\end{array}$} & 950 & $\begin{array}{l}\text { Subsidy for } \\
\text { global warming } \\
\text { countermeasures }\end{array}$ \\
\hline & & $\begin{array}{l}12,273 \text { for all } \\
\text { fossil fuels }\end{array}$ & & $\begin{array}{l}12,574 \\
\text { (estimated } \\
\text { by the } \\
\text { authors) }\end{array}$ & $\begin{array}{l}\text { No use (only } \\
\text { price incentive) }\end{array}$ \\
\hline $\begin{array}{l}\text { November } \\
2004\end{array}$ & $\begin{array}{l}\text { FY2005 tax } \\
\text { reform proposal } \\
\text { by MOE }\end{array}$ & $\begin{array}{l}655 \text { for all } \\
\text { fossil fuels }\end{array}$ & $\begin{array}{l}4 \% \text { reduction } \\
\text { from } 1990\end{array}$ & 490 & $\begin{array}{l}\text { General revenue: } \\
\text { JPY } 340 \text { billion } \\
\text { for global } \\
\text { warming } \\
\text { countermeasures } \\
\text { and JPY } 150 \\
\text { billion for } \\
\text { reduction of } \\
\text { social insurance } \\
\text { cost }\end{array}$ \\
\hline $\begin{array}{l}\text { November } \\
2005\end{array}$ & $\begin{array}{l}\text { FY2006 tax } \\
\text { reform proposal } \\
\text { by MOE }\end{array}$ & $\begin{array}{l}655 \text { for all } \\
\text { fossil fuels, } \\
\text { with } \\
\text { temporal } \\
\text { exemption } \\
\text { for gasoline, } \\
\text { diesel, jet } \\
\text { fuels }\end{array}$ & $\begin{array}{l}3.5 \% \\
\text { reduction } \\
\text { from } 1990\end{array}$ & 370 & $\begin{array}{l}\text { General revenue: } \\
\text { JPY } 370 \text { billion } \\
\text { for global } \\
\text { warming } \\
\text { countermeasures, } \\
\text { with partial } \\
\text { concession to } \\
\text { local } \\
\text { municipalities }\end{array}$ \\
\hline $\begin{array}{l}\text { November } \\
2006\end{array}$ & $\begin{array}{l}\text { FY2007 tax } \\
\text { reform proposal } \\
\text { by MOE }\end{array}$ & $\begin{array}{l}655 \text { for all } \\
\text { fossil fuels, } \\
\text { with } \\
\text { temporal } \\
\text { exemption } \\
\text { for gasoline, } \\
\text { diesel, jet } \\
\text { fuels }\end{array}$ & $\begin{array}{l}\text { No } \\
\text { description }\end{array}$ & 360 & $\begin{array}{l}\text { General revenue: } \\
\text { JPY } 360 \text { billion } \\
\text { for global } \\
\text { warming } \\
\text { countermeasures, } \\
\text { with partial } \\
\text { concession to } \\
\text { local } \\
\text { municipalities }\end{array}$ \\
\hline $\begin{array}{l}\text { November } \\
2007\end{array}$ & $\begin{array}{l}\text { FY2008 tax } \\
\text { reform proposal } \\
\text { by MOE }\end{array}$ & $\begin{array}{l}655 \text { for all } \\
\text { fossil fuels, } \\
\text { with } \\
\text { temporal } \\
\text { exemption } \\
\text { for gasoline, } \\
\text { diesel, jet } \\
\text { fuels }\end{array}$ & $\begin{array}{l}\text { No } \\
\text { description }\end{array}$ & 360 & $\begin{array}{l}\text { General revenue: } \\
\text { JPY } 360 \text { billion } \\
\text { for global } \\
\text { warming } \\
\text { countermeasures, } \\
\text { with partial } \\
\text { concession to } \\
\text { municipalities }\end{array}$ \\
\hline
\end{tabular}


Table 2 (continued)

\begin{tabular}{|c|c|c|c|c|c|}
\hline $\begin{array}{l}\text { Proposal } \\
\text { date }\end{array}$ & Description & $\begin{array}{l}\text { Tax rate }(\mathrm{JPY} \\
\left.\text { per t- }-\mathrm{CO}_{2}\right)\end{array}$ & $\begin{array}{l}\text { Expected } \\
\text { mitigation } \\
\text { effects }\end{array}$ & $\begin{array}{l}\text { Tax revenue } \\
\text { (JPY billion } \\
\text { per year) }\end{array}$ & $\begin{array}{l}\text { Use of tax } \\
\text { revenue }\end{array}$ \\
\hline $\begin{array}{l}\text { November } \\
2008\end{array}$ & $\begin{array}{l}\text { FY2009 tax } \\
\text { reform proposal } \\
\text { by MOE }\end{array}$ & $\begin{array}{l}655 \text { for all } \\
\text { fossil fuels, } \\
\text { with } \\
\text { temporal } \\
\text { exemption } \\
\text { for gasoline, } \\
\text { diesel, jet } \\
\text { fuels }\end{array}$ & $\begin{array}{l}\text { No } \\
\text { description }\end{array}$ & 360 & $\begin{array}{l}\text { General revenue: } \\
\text { revenue neutral } \\
\text { by reducing other } \\
\text { environmental tax } \\
\text { revenue }\end{array}$ \\
\hline $\begin{array}{l}\text { November } \\
2009\end{array}$ & $\begin{array}{l}\text { FY2010 tax } \\
\text { reform request } \\
\text { by MOE }\end{array}$ & 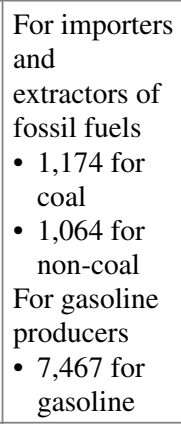 & $\begin{array}{l}\text { No } \\
\text { description (a } \\
\text { part of the } \\
\text { Challenge } 25 \\
\text { that will } \\
\text { achieve } 25 \% \\
\text { reduction } \\
\text { from } 1990 \text { by } \\
2020)\end{array}$ & 2,000 & $\begin{array}{l}\text { General revenue: } \\
\text { priority is given to } \\
\text { expenditures for } \\
\text { global warming } \\
\text { countermeasures } \\
\text { and tax cut } \\
\text { included in the } \\
\text { challenge } 25\end{array}$ \\
\hline $\begin{array}{l}\text { November } \\
2010\end{array}$ & $\begin{array}{l}\text { FY2011 tax } \\
\text { reform proposal } \\
\text { by MOE }\end{array}$ & $\begin{array}{l}300 \text { for all } \\
\text { fossil fuels }\end{array}$ & $\begin{array}{l}1 \% \text { reduction } \\
\text { from } 1990 \text { in } \\
2020\end{array}$ & 240 & $\begin{array}{l}\text { Use for mitigation } \\
\text { measures of } \\
\text { energy-derived } \\
\mathrm{CO}_{2}\end{array}$ \\
\hline $\begin{array}{l}\text { November } \\
2011\end{array}$ & $\begin{array}{l}\text { FY2012 tax } \\
\text { reform proposal } \\
\text { by MOE } \\
\text { (implemented } \\
\text { from FY2012) }\end{array}$ & $\begin{array}{l}289 \text { for all } \\
\text { fossil fuels, } \\
\text { starting from } \\
1 / 3 \text { of } 289, \\
\text { raised to } 2 / 3 \\
\text { of } 289 \text { in } \\
\text { April } 2014 \\
\text { and raised to } \\
289 \text { in April } \\
2016\end{array}$ & $\begin{array}{l}\text { No } \\
\text { description }\end{array}$ & $\begin{array}{l}262 \text { (normal } \\
\text { years) }\end{array}$ & $\begin{array}{l}\text { Use for mitigation } \\
\text { measures of } \\
\text { energy-derived } \\
\mathrm{CO}_{2}\end{array}$ \\
\hline
\end{tabular}

Source MOE, 'Greening taxation', accessed 15 January 2020 at https://www.env.go.jp/policy/tax/ kento.html, adopted by the authors

can be used to reduce other taxes that have the effect of distorting the market, in order to attain additional benefit of further improvement in resource allocation efficiency by correcting market distortions (the second dividend). For this form of the double dividend hypothesis, partial equilibrium model analyses by Nichols (1984), Terkla (1984), and Lee and Misiolek (1986) in the 1980s provided results supporting the hypothesis (Schob 2003). There are various variations in the double dividend hypothesis in terms of the definition of the second dividend such as an increase in employment rather than general GDP growth (e.g., Bovenberg and van der Ploeg 1998) or 
in the effect of correcting inequality in the income distribution (e.g., Klenert et al. 2016). In either case the possibility of double dividend from carbon tax can contribute to improve social and political acceptability of carbon tax. In Japan, however, the possibility of double dividend through revenue recycling to reduce other taxes or social insurance cost was reflected only in the MOE's tax proposals in 2004 and 2009, and the implemented Global Warming Countermeasure Tax does not have this possibility. Replacing existing taxes, such as corporate tax and income tax, with carbon tax in order to pursue double dividend would have financial implications to related ministries, not only MOE and the Ministry of Finance but also the Ministry of Economy, Trade and Industry, the Ministry of Health, Labor and Welfare, and so on. Consequently, incorporation of double dividend feature into carbon tax very likely requires inter-ministerial coordination, which might have hindered active discussion on double dividend issues in Japan.

\subsection{The Current Sectoral Effective Carbon Rates in Japan}

Broadly, there are three types of energy taxes in Japan, that is, upstream fossil fuel tax (the Petroleum and Coal Tax), downstream fossil fuel taxes (the Gasoline Tax, the Light Fuel Oil Tax, and the Aviation Fuel Tax), and electricity tax (the Electric Power Development Promotion Tax). The tax rates of downstream fossil fuel taxes are in general high, e.g. that of the Gasoline Tax is around USD 200/t- $-\mathrm{CO}_{2}$ and that of the Light Fuel Oil Tax is around USD 100/t- $-\mathrm{CO}_{2}$, but only selected types of fossil fuels are covered (Kawakatsu et al. 2017). Upstream fossil fuel tax, i.e. the Petroleum and Coal Tax, is levied on the import or extraction of all types of fossil fuels including natural gas, and the Global Warming Countermeasure Tax is implemented as an additional tax on the Petroleum and Coal Tax (Arimura and Iwata 2015). It should be noted that tax rates of the Petroleum and Coal Tax vary across different types of fossil fuels, i.e., around USD 7/t- $\mathrm{CO}_{2}$ for crude oil, USD $4 / \mathrm{t}-\mathrm{CO}_{2}$ for natural gas, and USD 2.7/t- $\mathrm{CO}_{2}$ for coal, which would give price advantage to coal against other cleaner fossil fuels.

Some opponents to carbon pricing often claim that Japan has already implemented quite high carbon pricing through the abovementioned energy taxes. The effective carbon rates estimated by OECD (2016) shed light on this claim. As shown in Table 1, Japan's effective carbon rate of road transportation energy is EUR $188.8 / \mathrm{t}-\mathrm{CO}_{2}$, which is higher than the average of listed countries in Table 1 (EUR 146.6/t- $\mathrm{CO}_{2}$ ) but not extremely high among OECD countries. In terms of national average effective carbon rates, Japan is EUR 34.8/t- $\mathrm{CO}_{2}$, which is lower than the average of listed countries in Table 1 (EUR 43.9/t-CO CO $_{2}$.

In order to identify potential of carbon pricing in Japan further, we estimated Japan's sectoral average effective carbon rates of 6 sectors, that is, the road transportation, the offroad transportation, the industry, the agriculture and fishing, the residential and commercial, and the electricity sectors, as shown in Table 3. 
Table 3 Sectoral effective carbon rates of Japan

\begin{tabular}{l|c|l|l}
\hline Sector & $\left.\begin{array}{l}\text { Average ECR } \\
(\text { EUR/t-CO }\end{array}\right)$ & Emission $\left(1000 \mathrm{t}-\mathrm{CO}_{2}\right)$ & Emission share $(\%)$ \\
\hline Road transport & 188.3 & 196,028 & 14.7 \\
\hline Offroad transport & 56.7 & 20,719 & 1.6 \\
\hline Industry & 3.3 & 451,225 & 33.8 \\
\hline $\begin{array}{l}\text { Agriculture and } \\
\text { fishing }\end{array}$ & 0.8 & 10,237 & 0.8 \\
\hline $\begin{array}{l}\text { Residential and } \\
\text { commercial }\end{array}$ & 5.5 & 150,165 & 11.2 \\
\hline Electricity & 10.4 & 508,103 & 38.0 \\
\hline
\end{tabular}

Source OECD (2016), adopted by the authors

It is striking that the average effective carbon rate of the industrial sector, which emit $33.8 \%$ of total carbon emissions, is EUR $3.3 / \mathrm{t}-\mathrm{CO}_{2}$, which is only marginally above the rate of Global Warming Countermeasure Tax. In terms of effective carbon rate it is clear that only transportation sectors (road transportation and offroad transportation) bear disproportionally heavy burden, which may result in sub-optimal mitigation outcome as a whole country.

\section{Expectations for Carbon Pricing in Japan}

\subsection{Discussion on Required Price Level}

As we discussed in the previous section, the current carbon pricing schemes in Japan are modest and there is a room to upgrade them to exploit full potential of carbon pricing in the context of decarbonization transition. The first key issue is adequate level of carbon pricing. In order to get ideas from the existing literature, it seems important to distinguish two approaches in estimating the carbon price corresponding to the given reduction target. One is the marginal abatement cost approach, which assumes that the carbon price to achieve the given reduction target is equal to the marginal abatement cost corresponding to that target, and the other is explicit carbon pricing approach in which the reduction target is achieved as a result of stakeholders response to explicit carbon pricing. In hypothetical first best world two approaches result in the same carbon price, but this does not hold in the real world as explained below.

The marginal abatement cost is the cost to reduce one unit in addition to the current amount of abatement. Since the cost to reduce one unit differs depending on abatement technologies and the amount of abatement, and since it is used from less expensive abatement technologies to achieve the required abatement, the marginal abatement cost increases as the required amount of emission reduction increases 
(Fig. 2). When the marginal abatement cost corresponding to the given reduction target is collected as a carbon price, the reduction target is achieved as a result of the emitter's rational action of cost minimization. In this case, the marginal abatement cost corresponding to the given reduction target is equal to the carbon price to achieve the target (Fig. 2). IPCC (2018) reports the marginal abatement costs in the scenarios corresponding to the $1.5^{\circ} \mathrm{C}$ and $2^{\circ} \mathrm{C}$ targets as the prices of carbon emissions.

On the other hand, Kesicki and Ekins (2012) point out that an approach in which reduction targets are achieved through the introduction of a carbon price equal to the marginal abatement cost corresponding to the reduction target does not reflect the various interactions associated with the dynamic processes, and it is necessary to consider marginal abatement costs separately from explicit carbon prices such as carbon taxes and ETS. Bataille et al. (2016) point out that prior to COP 15, majority of research focused on the marginal abatement cost curve for discussing economically efficient emission reductions since the main challenge there was partial emission reductions, but when addressing the challenge of full decarbonization, such as the DDPP, the marginal abatement cost approach is not useful because it may lead to lock-into carbon-intensive infrastructure and technologies or solutions that are inconsistent with social and economic priorities. For utilizing carbon pricing to realize a decarbonized society, it is important to go beyond the framework of the statistic equilibrium analysis of the marginal abatement cost approach and to conduct a dynamic analysis of the processes that significantly change the marginal abatement cost curve itself and the possibility of lowering total emissions and target reductions through a reduction of emitting activities as a result of influencing decision-making of all actors such as producers, consumers, and investors.

For example, the introduction of carbon pricing gives renewable energy a price advantage over fossil fuels, while the introduction of renewable energy in large quantities as a result of this price advantage makes renewable energy technologies

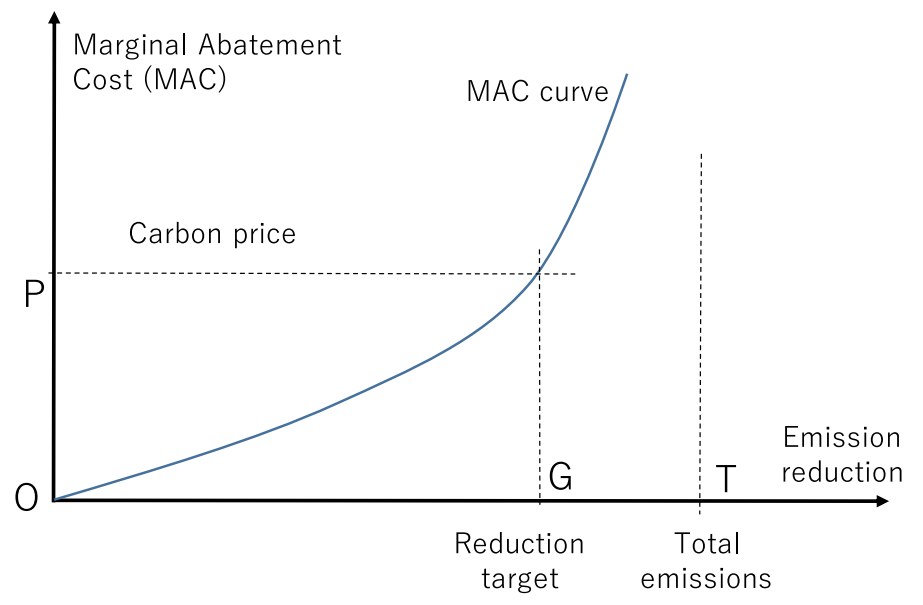

Fig. 2 Marginal abatement cost curve and carbon price. Source The authors 


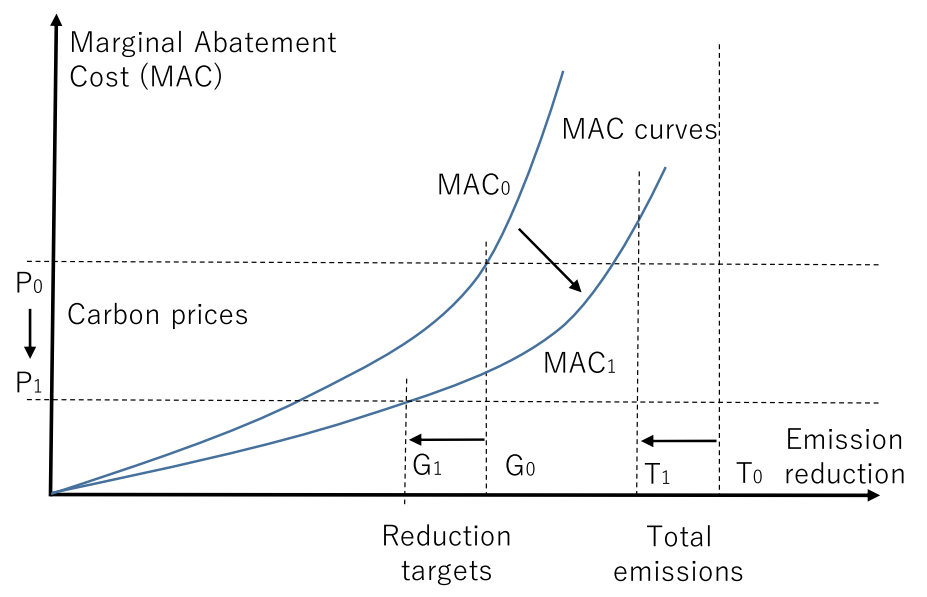

Fig. 3 Possibility of lowering carbon price through various dynamic effects. Source The authors

cheaper due to economies of scale, and this virtuous cycle will lead to substantial emission reduction. Taking these dynamic effects into account, the explicit carbon price required to achieve the reduction target is expected to be substantially lower than the corresponding marginal abatement cost for achieving the reduction target in the statics framework, as illustrated in Fig. 3.

Furthermore, the downward shift in the marginal reduction cost curve and the reduction in total emissions can also be caused by systemic changes such as the transition to a digital economy or a circular economy, which are not necessarily caused by the introduction of carbon pricing. Obviously the above argument still applies in this case. Regardless of the impact of carbon pricing, the dynamic analysis of system conversions that significantly change the marginal abatement cost curve itself and the possibility of lowering total emissions and the reduction target through a reduction in emitting activities is important to support actual implementation of carbon pricing.

In addition to the above arguments, the fact that individual bounded rationality plays a major role in real-world decision-making can also be a factor in the discrepancy between the marginal abatement cost estimates and the carbon price. It is known that there are negative marginal abatement costs, i.e., technologies that benefit from the implementation of reduction measures, when a marginal abatement cost curve is drawn by ordering the reduction cost per unit and the amount that can be reduced for each reduction measure technology from the one with the lowest reduction cost per unit. The fact that not all of these technologies with negative marginal abatement costs have been introduced shows that in the real world, the assumption that all measures with marginal abatement costs lower than the carbon price will be implemented is not necessarily valid. Therefore, a distinction needs to be made between estimating the marginal abatement cost corresponding to a given reduction target 
and how much is reduced through each stakeholder's responses when that marginal abatement cost is introduced as an explicit carbon price.

As the above discussion suggests, estimated carbon prices in consistent with decarbonization transition significantly vary between two approaches. In general, the marginal abatement cost approach resulted in much higher carbon prices than the explicit carbon pricing approach.

IPCC (2018) estimates global marginal abatement costs for emission pathways meeting the $2^{\circ} \mathrm{C}$ target to be USD $15-220 / \mathrm{t}-\mathrm{CO}_{2}$ eq (2010 prices) in 2030 and USD $45-1,050 / \mathrm{t}-\mathrm{CO}_{2}$ eq (2010 prices) in 2050, while marginal abatement costs for emission pathways meeting the $1.5^{\circ} \mathrm{C}$ target to be USD $135-6,050 / \mathrm{t}-\mathrm{CO}_{2} \mathrm{eq}$ (2010 prices) in 2030 and USD 245-14,300/t- $\mathrm{CO}_{2}$ eq (2010 prices) in 2050. Oshiro et al. (2017) estimated marginal abatement costs using the AIM/Enduse [Japan] model, a sequential dynamic bottom-up energy model, for seven different scenarios for Japan's decarbonization paths corresponding to the $2^{\circ} \mathrm{C}$ and $1.5^{\circ} \mathrm{C}$ targets, with and without utilizing carbon sequestration through nuclear power and bioenergy CCS (BECCS), and with and without making early abatement efforts in 2030 that exceed the NDC reduction target. It is also argued that without the use of BECCS, the $1.5^{\circ} \mathrm{C}$ target cannot be achieved and the marginal reduction cost in 2050 under the $2^{\circ} \mathrm{C}$ target achievement scenario rises to USD $860 / \mathrm{t}-\mathrm{CO}_{2}$. Sugiyama et al. (2019) analyzed the decarbonization paths of achieving the 2030 NDC and $80 \%$ reduction in 2050 using 7 different models with different characteristics, including sequential and full dynamics, global model and Japan single country model, general equilibrium model and partial equilibrium model, and estimated the marginal abatement cost in 2030 as USD 44-346/t- $\mathrm{CO}_{2}$ (median USD 150/t- $\mathrm{CO}_{2}$ ) and the marginal abatement cost in 2050 as USD 273-7,730/t- $\mathrm{CO}_{2}$ (median USD 2,818/t-CO $\mathrm{CO}_{2}$.

On the other hand, the studies in explicit carbon pricing approach estimate relatively moderate carbon price to achieve decarbonization transition. DDPP (2015) identifies carbon pricing as an important element in all policy packages, but Canada and France are the only countries to place explicit carbon pricing in their policy packages in the DDPP country reports (Bataille et al. 2015; Criqui et al. 2015). As part of its policy to reduce GHG emissions by $90 \%$ from 2005 levels by 2050, Canada assumes to introduce carbon pricing at CAD 50/t- $\mathrm{CO}_{2}$ in 2020 and raise it by CAD $10 / \mathrm{t}-\mathrm{CO}_{2}$ each year thereafter until it reaches $\mathrm{CAD} 350 / \mathrm{t}-\mathrm{CO}_{2}$ in 2050 through a combination of an ETS for heavy industry and a flexible carbon pricing system with an upstream ETS or carbon tax option for other stakeholders. Revenues from carbon pricing are assumed to be used to reduce income taxes for individuals and corporations (Bataille et al. 2015). In France, as part of the policy to reduce GHG emissions by $75 \%$ of 1990 levels by 2050, a carbon tax of EUR 90/t- $\mathrm{CO}_{2}$ in 2030 and EUR $280 / \mathrm{t}-\mathrm{CO}_{2}$ in 2050 is introduced for all sectors under the scenario of $50 \%$ share of nuclear power and $40 \%$ share of renewable energy in the power supply mix in 2050 , and a carbon tax of EUR 120/t- $\mathrm{CO}_{2}$ in 2030 and EUR 360/t- $\mathrm{CO}_{2}$ in 2050 is introduced for all sectors under the scenario of $25 \%$ share of nuclear power and $70 \%$ share of renewable energy in the power supply mix in 2050, and the carbon tax revenue is returned equally to households (Criqui et al. 2015). Rockström et al. (2017) argue that in an effort to achieve a "roadmap for rapid decarbonization" to achieve net 
zero $\mathrm{CO}_{2}$ emissions globally by 2050 , they would eliminate all fossil fuel subsidies by 2020, which currently amount to USD 500-600 billion per year, and introduce an explicit carbon price of at least USD 50/t- $\mathrm{CO}_{2}$ for all $\mathrm{CO}_{2}$ emissions in 2020 through international ETS scheme and a carbon tax on air and sea transport, gradually increasing to a level above USD $400 / \mathrm{t}-\mathrm{CO}_{2}$ by 2050 . This roadmap assumes that all $\mathrm{CO}_{2}$ emissions, estimated to be around $5 \mathrm{Gt}$ by 2050 , will be captured by BECCS to achieve net zero $\mathrm{CO}_{2}$ emissions. To realize a decarbonized society in Japan, Kojima et al. (2018) propose a policy package consisting of carbon tax and a tax recycling scheme in which a portion of the carbon tax revenues is allocated to energy efficiency investments in order to achieve the 2030 NDC target and the long-term goal of the Global Warming Action Plan, an $80 \%$ reduction by 2050. Based on E3ME macro-measurement model analysis, Kojima et al. (2018) propose a carbon tax of JPY 11,400/t- $\mathrm{CO}_{2}$ (around USD 100/t- $\mathrm{CO}_{2}$ ) in 2030 and JPY 57,300/t- $\mathrm{CO}_{2}$ (around USD 500/t- $-\mathrm{CO}_{2}$ ) in 2050 in a phased manner from 2021 to 2050, with allocating $2-4 \%$ of the carbon tax revenue to energy efficiency investments and returning the remainder of the tax revenue to households in a lump-sum manner. More recently, Kobayashi et al. (2019) incorporate an assumption of a full transition to a digital economy and estimate the carbon tax rate to achieve $80 \%$ reduction in $\mathrm{CO}_{2}$ emissions in 2050 (compared to 2013), which corresponds to the $2^{\circ} \mathrm{C}$ target, and zero $\mathrm{CO}_{2}$ emissions in 2050 , which corresponds to the $1.5^{\circ} \mathrm{C}$ target, using the static computable general equilibrium (CGE) model. Their assumption of a full transition to a digital economy include widespread use of artificial intelligence (AI), the Internet of Things (IoT), and big data. In introducing the carbon tax, the existing energy tax portion of the tax is reduced so as not to be double taxed with the existing energy tax. It is also assumed that all carbon tax revenues will be returned to households. This study assumes that $\mathrm{CO}_{2}$ emissions in 2050 will be reduced by $61 \%$ in comparison with 2013 even without carbon pricing, because the transition to the digital economy will result in a reduction in manufacturing and a shift to an industrial structure dominated by the service industry along with a decline in the population and an aging of the population. Furthermore, this study assumes a structural change accompanying the transition to the digital economy, such as the use of plastic as a substitute for steel in automobile manufacturing due to the improved safety of automobile traffic caused by the spread of automated driving, or an $80 \%$ reduction in the number of automobiles due to the development of the sharing economy, and the elimination of automobile purchases by ordinary households. Based on these assumptions, Kobayashi et al. (2019) conclude that a carbon tax of JPY 9,700/t-CO (around USD 90/t-CO would be necessary to achieve $80 \%$ reduction, which means additional $19 \%$ reduction on the baseline reduction of $61 \%$, with an additional assumption that carbon pricing triggers the introduction of CCS and additional renewable energy. Without assuming carbon pricing-induced CCS and additional renewable energy deployment, the carbon tax rate required to achieve an $80 \%$ reduction in 2050 will jump to more than JPY 30,000/t- $\mathrm{CO}_{2}$ (around USD 270/t-CO $\mathrm{CO}_{2}$ ). In order to further reduce emissions and achieve zero emissions in 2050, Kobayashi et al. (2019) estimate that a carbon tax of JPY 21,400/t- $\mathrm{CO}_{2}$ (around USD 200/t- $-\mathrm{CO}_{2}$ ) will be required, assuming the introduction of CCS and additional renewable energy through carbon pricing. 


\subsection{Careful Consideration for Revenue Recycling}

The revenue generation function of carbon pricing is associated with both potential and challenges and it must be carefully considered.

In terms of potential, there are various options of spending of the revenue of carbon pricing. In case of the Global Warming Countermeasure Tax its revenue is solely spent for global warming countermeasures. However as explained in Sect. 3, wisely designed revenue recycling may be able to achieve double dividend in some forms (Chap. 13). Considering the problems Japan is facing now, such as low birthrate and aging population, declining local population, in addition to various challenges associated with decarbonization transition including infrastructure investment, revenue recycling for solving these problems may generate double dividend or even multiple dividend. When the level of carbon price will be as high as discussed in 4.1 , the expected revenue could be very large and appropriate revenue recycling could have huge positive impacts.

On the other hand, there is a potential conflict between the mitigation function and the revenue generating functions of carbon pricing (Morotomi 2000). This concern is particularly important when carbon pricing is introduced in order to achieve major emissions reduction. For example, if Japan could achieve an $80 \%$ emissions reduction by 2050 with carbon tax as one of key policy instruments for this purpose, the tax base of the carbon tax would fall by $80 \%$. Some may argue that no tax can escape revenue fluctuations, but the point here is not just revenue fluctuations but also implications for policy design. If, for example, a carbon tax is intended to generate stable revenue, either a sufficiently low tax rate should be chosen or a gradually increasing tax schedule would be needed to compensate for the reduction in the tax base. In the former case, the mitigation effect is sacrificed. The latter case, starting with an initial low rate may be reasonable as in any case, but a very high rate of carbon tax would be politically infeasible and keeping a certain revenue level would become very difficult.

\section{Conclusion}

This chapter reviewed the current carbon pricing in Japan, in terms of not only explicit carbon pricing but also effective carbon rates, along with the current status of carbon pricing worldwide, in the context of global climate policy after the Paris Agreement and the IPCC $1.5^{\circ} \mathrm{C}$ Special Report (IPCC 2018).

There seems a general agreement among the literature addressing decarbonization pathways corresponding to post Paris Agreement climate policy that carbon pricing with high price level plays indispensable roles to realize systemic transition towards decarbonized society. The rationale is that high level of carbon pricing can provide effective and consistent signals to all stakeholders which is essential to harmonize their decentralized decision making towards decarbonization. 
In this context, there is a large potential of improvement in Japan's carbon pricing schemes. Japan has implemented nationwide carbon tax, i.e. the Global Warming Countermeasure Tax, since April 2012. The tax rate of this carbon tax is JPY 289/t$\mathrm{CO}_{2}$ (around USD 2.6/t- $\mathrm{CO}_{2}$ ), which is one of the lowest among carbon pricing initiatives in the world. There are also two municipality level ETS schemes in Tokyo (since 2010) and in Saitama (since 2011), which will be addressed in Chaps. 6 and 7 , respectively. There is an argument that Japan has already implemented high level carbon pricing in terms of various forms of energy taxes. However, the nationwide average effective carbon rate of Japan is EUR 34.8/t-CO $\mathrm{CO}_{2}$ according to OECD (2016), which is lower than the average effective carbon rates of OECD countries and its key partner countries (EUR 43.9/t- $\mathrm{CO}_{2}$ ). Our estimates of Japan's sectoral average effective carbon rates based on OECD (2016) highlight that only the transportation sectors are associated with high effective carbon rates. In Japan the sectoral average effective carbon rates of two large emitters, i.e. the industrial sector and the electricity sector, are EUR 3.3/t- $\mathrm{CO}_{2}$ and EUR 10.4/t- $\mathrm{CO}_{2}$, respectively. For improving mitigation efficiency of carbon pricing, one candidate option is energy tax reform based on carbon content of energy carriers, which is discussed in Chap. 11.

In order to exploit full potential of carbon pricing in materializing decarbonization transition, much higher carbon price than the current Global Warming Countermeasure Tax is needed. In order to get ideas about adequate level of carbon pricing from the existing literature, we distinguished two approaches in estimating carbon price corresponding to the given reduction target, that is, the marginal abatement cost approach that assumes carbon price to achieve the given reduction target is equal to the marginal abatement cost corresponding to the target, and the explicit carbon pricing approach in which the reduction target is achieved as a result of stakeholders response to explicit carbon pricing. In general the former is associated with much higher carbon prices than the latter due to lack of dynamic interactions between carbon pricing and marginal abatement cost curves, such as downward shift of marginal abatement cost curves due to innovation induced by carbon pricing. The literature based on the explicit carbon pricing approach tend to estimate carbon prices corresponding to decarbonization paths at around USD 100-500/t- $\mathrm{CO}_{2}$ (c.f. DDPP 2015; Rockström et al. 2017; Kojima et al. 2018; Kobayashi et al. 2019).

Another important issue of carbon pricing is the revenue recycling design. As in many European cases green tax reform in which revenue of carbon tax is spent to reduce other forms of taxes or social insurance costs may result in double dividend (Chap. 13), or even multiple dividend. While careful consideration of revenue recycling design is necessary because of potential conflict between the mitigation function and the revenue generating functions of carbon pricing, carbon pricing with adequate price level with wisely designed revenue recycling is expected to play important roles to materialize decarbonization transition. 


\section{References}

Arimura TH, Iwata K (2015) Economic impacts of the GHG tax on the Japanese economy: shortterm analysis. An evaluation of Japanese environmental regulations. Springer, Dordrecht, pp $145-173$

Arimura T, Takeda S, Onuma H (2018) Double dividend of carbon pricing. Rev Environ Econ Policy Stud 11(2):73-76 (in Japanese)

Asakawa K, Matsuo Y, Sunhee S, Rocamora AR (2016) Case studies on analysis of political debate on carbon pricing, especially carbon-tax, in Japan and the other countries. In: Society for environmental economics and policy studies, 10 Sept 2016 (in Japanese)

Bataille C, Sawyer D, Melton N (2015) Pathways to deep decarbonization in Canada, SDSN-IDDRI

Bataille C, Waisman H, Colombier M, Segafredo L, Williams J (2016) The deep decarbonization pathways project (DDPP): insights and emerging issues. Clim Policy 16(sup1):S1-S6

Bovenberg AL, van der Ploeg F (1998) Consequences of environmental tax reform for unemployment and welfare. Environ Resource Econ 12:137-150

Criqui P, Mathy S, Hourcade JC (2015) Pathways to deep decarbonization in France, SDSN-IDDRI DDPP (2015) Pathways to deep decarbonization 2015 Report, SDSN-IDDRI

De Mooij RA (2000) Environmental taxation and the double dividend. North-Holland, Amsterdam Environmental Agency (1997) Measures for climate change mitigation and environmental taxation, Gyousei (in Japanese)

Force MT (1998) Economic instruments and the business use of energy: conclusions. Marshall Task Force on the Industrial Use of Energy, HM Treasury, London

Fullerton D, Metcalf GE (1997) Environmental taxes and the double-dividend hypothesis: did you really expect something for nothing? National Bureau of Economic Research, Cambridge, MA

Goulder LH (1995) Environmental taxation and the 'double dividend': a reader's guide. Int Tax Publ Finance 2:157-184

IPCC (2018) Global warming of $1.5^{\circ} \mathrm{C}$ : an IPCC special report on the impacts of global warming of $1.5{ }^{\circ} \mathrm{C}$ above pre-industrial levels and related global greenhouse gas emission pathways, in the context of strengthening the global response to the threat of climate change, sustainable development, and efforts to eradicate poverty. Intergovernmental Panel on Climate Change, Geneva

Kawakatsu T, Lee SC, Rudolph S (2017) The Japanese carbon tax and the challenges to low-carbon policy cooperation in East Asia. Kyoto University Graduate School of Economics Discussion Paper Series No. E-17-009

Kesicki F, Ekins P (2012) Marginal abatement cost curves: a call for caution. Clim Policy 12(2):219_ 236

Klenert D, Schwerhoff G, Edenhofer O, Mattauch L (2016) Environmental taxation, inequality and engel's law: the double dividend of redistribution. Environ Resource Econ 71(3):605-624

Kobayashi T, Tahara K, Kawasaki Y, Ochiai K, Suzuki T, Kobayashi H, Sayama S, Iwata K (2019) Transition to digital economy: $60 \%$ reduction of greenhouse gases-environmental tax of JPY 10,000 in order to achieve 80\% reduction in 2050. Japan Centre for Economic Research, 7 May 2019 (in Japanese)

Kojima S, Asakawa K, Lee SC, Chewpreecha U, Suk S (2018) Green tax reform proposal towards realisation of long-term low carbon vision. Rev Environ Econ Policy Stud 11(2):82-86 (in Japanese)

Kreiser L, Andersen M, Olsen B, Speck S, Milne J, Ashiabor H (2015) Carbon pricing: design, experiences and issues. Edward Elgar, Cheltenham

Lee DR, Misiolek WS (1986) Substituting pollution taxation for general taxation: some implications for efficiency in pollution taxation. J Environ Econ Manage 13:338-347

Morotomi T (2000) Theory and practice of environmental tax. Yuhikaku, Tokyo (in Japanese)

Nichols AL (1984) Targeting economic incentives for environmental protection. MIT Press, Cambridge 
Nordhaus WD (2010) Economic aspects of global warming in a post-Copenhagen environment. Proc Natl Acad Sci 107(26):11721-11726

OECD (2016) Effective carbon rates: pricing $\mathrm{CO}_{2}$ through taxes and emissions trading systems. OECD Publishing, Paris

Oshiro K, Masui T, Kainuma M (2017) Transformation of Japan's energy system to attain net-zero emission by 2050. Carbon Manage. https://doi.org/10.1080/17583004.2017.1396842

Patt A, Lilliestam J (2018) The case against carbon prices. Joule 2(12):2494-2498

Pearce D (1991) The role of carbon taxes in adjusting to global warming. Econ J 101(407):938-948

Rockström J, Gaffney O, Rogelj J, Meinshausen M, Nakicenovic N, Schellnhuber HJ (2017) A roadmap for rapid decarbonization. Science 355(6331):1269-1271

Schneider S, Goulder LH (1997) Achieving low-cost emissions targets. Nature 389(6646): 13

Schob R (2003) The double dividend hypothesis of environmental taxes: a survey. Nota di Lavoro, Fondazione Eni Enrico Mattei, no 60

Sugiyama M, Fujimori S, Wada K, Endo S, Fujii Y, Komiyama R, Kato E, Kurosawa A, Matsuo Y, Oshiro K, Sano F, Shiraki H (2019) Japan's long-term climate mitigation policy: multi-model assessment and sectoral challenges. Energy 167:1120-1131

Terkla D (1984) The efficiency value of effluent tax revenues. J Environ Econ Manage 11:107-123

Tvinnereim E, Mehling M (2018) Carbon pricing and deep decarbonisation. Energy Policy 121:185189

WBCSD (2019) Carbon pricing, WBCSD policy paper

World Bank (2019a) Carbon pricing leadership report 2018/19. World Bank, Washington, D.C.

World Bank (2019b) State and trends of carbon pricing 2019. World Bank, Washington, D.C.

Dr. Satoshi Kojima is a principal coordinator at the Institute for Global Environmental Strategies (IGES). He has conducted various quantitative policy impact assessments using computable general equilibrium models and he has led research projects on sustainable development policy including sustainable resource management and sustainable ecosystem use. He studied environmental economics at the University of York in UK and received a Ph.D. in 2005.

Dr. Kenji Asakawa completed a Master of Urban Environment Engineering in Architectural Engineering at the Waseda University Faculty of Science and Engineering. While working at a consulting company on environmental preservation projects based on ODA and being involved in environmental impact assessment both in Japan and overseas, he obtained a class-1 certification as an Architect and as a Professional Engineer. Subsequently, after working in the development of global warming mitigation, including CDM projects, and climate policy, he obtained his Juris Doctor from Omiya Law School and passed the National Bar Examination.

Open Access This chapter is licensed under the terms of the Creative Commons Attribution 4.0 International License (http://creativecommons.org/licenses/by/4.0/), which permits use, sharing, adaptation, distribution and reproduction in any medium or format, as long as you give appropriate credit to the original author(s) and the source, provide a link to the Creative Commons license and indicate if changes were made.

The images or other third party material in this chapter are included in the chapter's Creative Commons license, unless indicated otherwise in a credit line to the material. If material is not included in the chapter's Creative Commons license and your intended use is not permitted by statutory regulation or exceeds the permitted use, you will need to obtain permission directly from the copyright holder. 